\title{
Percutaneous Endoscopic Gastrostomy. Are we doing the better for all patients?
}

\author{
Luiz Eduardo Correia Miranda ${ }^{(\mathbb{D})}$, Diego Laurentino Lima ${ }^{2}$ (D), Marcel Rolland Ciro da Penha ${ }^{1}$ (D), \\ Ana Clara Miranda ${ }^{1}$, Matheus Stillner Eufrânio ${ }^{1}$
}

${ }^{1}$ Department of Surgery, Oswaldo Cruz University Hospital, Recife, Brazil

${ }^{2}$ Department of Surgery, Montefiore Medical Center, The Bronx, New York, USA

$\bigotimes_{\text {Luiz Eduardo Correia Miranda }}$ lecmiranda@gmail.com

Edited by: Juliana Ramos de Andrade
Enteral nutrition is the chosen route of feeding for patients who require nutrition support L therapy and are unable to maintain oral intake because of neurological or congenital diseases, cancer or other causes. For patients who require more than eight weeks of nutritional enteral support, a percutaneous endoscopic gastrostomy (PEG) is often indicated. ' Usually, these patients are old people suffering from chronic neurological disabilities. Although PEG is considered safe, efficient and cost effective, there is considerable short-term mortality and morbidity, and for patients with dementia, PEG has been discouraged because of associated high mortality. ${ }^{2,3}$

The indication of a medical treatment to a patient who will die in the near future is a futile indication. ' The patients will suffer the risks of PEG, and there will be charges which must be considered-all for zero benefits.

Improving the indication for PEG is quite important to avoid futile procedures. Authors have made efforts to investigate risk factors associated with early mortality after PEG. 1,4-10 Most of these investigations are retrospective surveys, which have natural limitations: no control group, no randomized patients and missing data. These surveys have demonstrated two main groups of risk factors related to early mortality after PEG: factors associated with malnutrition (hypoalbuminemia, anemia, malnutrition) or factors associated with chronic disease (diabetes, coronary disease, age, etc). 4,5,7,10-12 We recently published a paper that investigated the risk factors associated with 30 day mortality in patients who submitted to PEG at the Unimed Recife III Hospital. ' We concluded that anemia and a recent past of ICU hospitalization are risk factors related to 30-day mortality after PEG.

Medical associations have proposed guidelines to improve the quality of PEG indication. ${ }^{13,14}$ The main objective is avoiding PEG for patients with no good clinical indications. This is not an easy mission. There is a terrible ethical conflict in this question, especially for elderly patients. When the patients are not able to swallow their own food and water because of advanced age and chronic neurological impairment, relatives might exert some pressure on the doctor for a solution. If the doctor recommends PEG, he or she will impose a medical risk on the patient and, if nothing happens, PEG will artificially preserve the life with associated pain and suffering for a patient with severe sequelae. If the doctor does not indicate PEG, he or she will face the disappointment 
of relatives and caregivers, who often argue that the doctor will starve the patient to death.

We propose here a three-step answer for this complex request. First, it is essential to write an institutional clinical guideline considering the local aspects involved in this issue, managing the ethical conflicts, informed consent and the decision-making process against lawsuits and clearly defining the cases qualified for PEG. A medical committee to support the decisions should also be considered. Second, it is necessary to support and advise relatives-before the critical time-about the natural evolution of the disease and the risks and consequences of perpetuating the lives of severely impaired patients. This is an issue for a multidisciplinary team. Third, doctors should be aware of the intricate questions related to PEG indication and of the solutions for natural conflicts.

In conclusion, to recommend PEG as a definitive solution for patients who require long-term nutritional support is a complex issue involving technical and ethical details. Future research with a more suitable methodology should address the issue of risk factors related to early mortality, allowing the improvement of PEG indication and consequently avoiding futile procedures.

Luiz Eduardo Correia Miranda

https://orcid.org/0000-0002-7450-3212

Diego Laurentino Lima

https://orcid.org/0000-0001-7383-1284

Marcel Rolland Ciro da Penha

https://orcid.org/0000-0002-5781-6727

Ana Clara Miranda

https://orcid.org/0000-0001-6802-8032

Matheus Stillner Eufrânio

https://orcid.org/0000-0002-5684-2974

Conflicts of interest: The authors declare no conflict of interest.

\section{References}

1. Lima DL, Miranda LEC, da Penha MRC, Lima R, Dos Santos DC, Eufrânio MS, ... Pereira L. Factors Associated with 30-Day Mortality in Patients after Percutaneous Endoscopic Gastrostomy. Js/s 2021;25(3):Doi:10.4293/isls. 2021.00040

2. Ayman AR, Khoury T, Cohen J, Chen S, Yaari S, Daher $S, \ldots$ Mizrahi M. PEG Insertion in Patients With Dementia Does Not Improve Nutritional Status and Has Worse Outcomes as Compared With PEG Insertion for Other Indications.
J Clin Gastroenterol 2017;51(5):417-420 Doi: $10.1097 / \mathrm{mcg} .0000000000000624$

3. Brooke $J$ and $O j o$ O. Enteral nutrition in dementia: a systematic review. Nutrients 2015;7(4):24562468 Doi: $10.3390 /$ nu7042456

4. Agudo Tabuenca A, Altemir Trallero J, Gimeno Orna JA and Ocón Bretón MJ. Mortality risk factors after percutaneous gastrostomy: Who is a good candidate? Clin Nutr 2019;38(2):856-861 Doi:10.1016/i.clnu.2018.02.018

5. Abuksis $G$, Mor $M$, Plaut $S$, Fraser $G$ and Niv $Y$. Outcome of percutaneous endoscopic gastrostomy (PEG): comparison of two policies in a 4-year experience. Clin Nutr 2004;23(3):341346 Doi:10.1016/i.clnu.2003.08.001

6. Arora G, Rockey D and Gupta S. High In-hospital mortality after percutaneous endoscopic gastrostomy: results of a nationwide population-based study. Clin Gastroenterol Hepatol 2013;11(11):1437-1444.e1433 Doi:10.1016/i.cgh.2013.04.011

7. Limpias Kamiya KJL, Hosoe N, Takabayashi K, Hayashi Y, Fukuhara S, Mutaguchi M, ... Kanai T. Factors predicting major complications, mortality, and recovery in percutaneous endoscopic gastrostomy. JGH Open 2021;5(5):590-598 Doi:10.1002/igh3.12538

8. Löser C, Wolters S and Fölsch UR. Enteral longterm nutrition via percutaneous endoscopic gastrostomy (PEG) in 210 patients: a four-year prospective study. Dig Dis Sci 1998;43(1 1):25492557 Doi:10.1023/a:1026615106348

9. Anderloni A, Di Leo M, Barzaghi F, Semeraro R, Meucci G, Marino R, ... Gullotta R. Complications and early mortality in percutaneous endoscopic gastrostomy placement in lombardy: A multicenter prospective cohort study. Dig Liver Dis 2019;51(10):1380-1387 Doi:10.1016/i.dld.2019.03.024

10. Suzuki Y, Tamez S, Murakami A, Taira A, Mizuhara A, Horiuchi A, . . Urashima M. Survival of geriatric patients after percutaneous endoscopic gastrostomy in Japan. World J Gastroenterol 2010;16(40):5084-5091 Doi:10.3748/wig. v16.i40.5084

11. Barbosa M, Magalhaes J, Marinho C and Cotter J. Predictive factors of early mortality after percutaneous endoscopic gastrostomy placement: The importance of C-reactive protein. Clin Nutr ESPEN 2016;14:19-23 Doi:10.1016/j. clnesp.2016.04.029

12. Muratori R, Lisotti A, Fusaroli P, Caponi A, Gibiino $G$, Eusebi LH, ... Bazzoli F. Severe hypernatremia as a predictor of mortality after percutaneous endoscopic gastrostomy (PEG) placement. Dig Liver Dis 2017;49(2):181-187 Doi:10.1016/j. 
dld.2016.10.015

13. Bischoff SC, Austin P, Boeykens K, Chourdakis $M$, Cuerda $C$, Jonkers-Schuitema $C$, . . . Pironi L. ESPEN guideline on home enteral nutrition. Clin Nutr 2020;39(1):5-22 Doi:10.1016/i. clnu.2019.04.022
14. Löser C, Aschl G, Hébuterne X, Mathus-Vliegen EM, Muscaritoli $M$, Niv $Y$, . . . Skelly RH. ESPEN guidelines on artificial enteral nutrition-percutaneous endoscopic gastrostomy (PEG). Clin Nutr 2005;24(5):848-861 Doi:10.1016/i. clnu.2005.06.013 